\title{
Language Units of the Morphological Level in the Style of the Advertising Text
}

\section{Zuleykhan Kimovna Bedanokova}

\author{
Susanna Kaplanovna Bedanokova
}

\author{
Anzhela Anatolyevna Adzinova
}

\section{Svetlana Vladimirovna Lyapun}

Federal State Budget Institution of Higher Professional Education «Adyghe State University» (ASU) 385000, Maikop, street Pervomayskaya, 208, Russian Federation; Email: nisadgu@yandex.ru

\section{Doi:10.5901/mjss.2015.v6n5s2p204}

\section{Abstract}

\begin{abstract}
Studies of language of contemporary advertising prove the validity of assertions about the ability of advertising to form the taste of the language community. Sometimes ads are ahead of already existing norms of language, creating new images and models of verbal communication in the search for maximum efficiency of impact. The analysis of the most striking and noticeable trends of morphological level in the language of advertising is concentrated in the area of lexico-grammatical status of the nominal parts of speech: the development of the quantitative category in abstract noun word forms and making relative adjectives to be qualitative ones. Besides, in the area of the verbal lexical units one can observe expanding of verbal paradigms owing to new mandatory forms. The manifestation and activation of grammatical processes in the advertising text reflects not only the expansion of the arsenal of means of expression, but also the serious grammatical shifts that can be regarded as a means forming the stylistic unity of the advertising text.
\end{abstract}

Keywords: advertising text, morphological means of language, parts of speech stylistics.

\section{Introduction}

The life of modern person is largely associated with mass media and, in particular with advertising, which now has stepped beyond the economic sphere. Modern advertising as a sociocultural phenomenon primarily reflects the state of culture and society, the way people live, often forming it and influencing it indirectly through a range of methods and techniques; it shows a modern, living language, it is a kind of mirror of the changes in the language, which makes the need to study the processes taking place in the current text field. Studies prove the validity of assertion about the ability of advertising to influence the literary and language usage, to guide linguistic taste in a society. Occasionally advertising keeps ahead of already existing norms of language, creating new images and models of verbal communication in the trying to maximize the impact efficiency that only later would become an integral part of the linguistic culture. Observations of the language of advertising allowed scholars, on the one hand, to identify common patterns of linguopragmatic development of this type of speech activity, and on the other, to consider advertising as a reflection of active processes in the Russian language in general. The relevance is determined by the fact that modern advertising text regenerates and develops earlier existing means of expression, in particular, at the morphological level of language.

\section{Methods}

Theoretical and methodological basis of the study were the provisions of anthropocentric linguistics developed by Émile Benveniste (1966) in the framework of communicative grammar and language level model, as well as the heritage of Charles Bally (1961) of the expressive possibilities of morphological means in a literary text. A dynamic approach to the study of the grammatical potential in advertising is relevant and it is based on the identification and examination of morphological trends as the expressive resources of the advertising text. Solution to a problem is supported by the fact that the foundations of the dynamic study of grammar are laid down in the classical works by L. V. Shcherba, A. M. Peshkovsky, G. O. Vinokur, V. V. Vinogradov, R. O. Jakobson, as well as in the studies of such foreign linguists as Charles Bally, Jerzy Kuryłowicz. The problem of noun declinability in different Slavic languages as one of the 
morphological parameters of grammar is embodied in the work of Ursula Doleschal (2001), the problem of learning the language of advertising, as well as recommendations for the compilation of slogans were developed by Richard J. Valladares (2005). The study of linguistic aspects of advertising, more precisely the analysis of the language of advertising on the lexical, syntactic and stylistic levels are found in the work of Ruth Römer (1980), summarizing of the recommendatory nature is contained in the multi-authored monograph of William D. Wells, Sandra Moriarty, John Burnett (2000). Formation of the advertising style in the Russian language can be seen both as a hypothesis and as an established fact, owing to the numerous foreign and domestic researches of linguists (Kara-Murza, 1997; Kakorin 2003, Maximov, 2004; Pirogov, Baranov, Parshin, 2000; Zirka, 2008) as in the Russian language advertising one can observe processes enabling to ascertain regular linguistic phenomena. We believe that numerous studies on the Russian language style (Gvozdev, 1967; Vassilyev, 1976 Zemskaya, Kitaygorodskaya, Shiryaev, 1981; Solganik, 1991; Kozhin, 1993; Golub, 1997; Kokhta, 1998; Sannikov, 1999; Moskvin, 2000) allow using the practical and conceptual apparatus to generalize some observations in the language of the advertising text. Formulating the problem - to stylistically highlight morphological phenomena in the language of advertising - at first one should refer to the main aspects of their study in the Russian language stylistics.

The Russian philology is quite actively studying the functional aspect of the mass media language, which is particularly important for the methodological aspect of this work. Identification of certain grammatical tendencies in the functioning of the mass media language and oral public speech suggested by M. Ya. Glovinskaya contributes to understanding not only the laws of grammar, correlated with a specific object, but also helps understand the general principles of functioning of the grammatical system, its potential implemented in the process of speech activity (Glovinskaya, 1996). One of the important sources of advertising text expressiveness is the variation of the sign, to the study of which are dedicated fundamental researches (Ikovich, 1968; Gorbachevich, 1978; Graudina 1980; Valgin, 2001) that served as a basis for the identification and interpretation of different morphological forms of one lexical unit.

In "Essays on the Style of the Russian language" A. .N. Gvozdev writes: "In order to understand the specificity of studying morphological phenomena in stylistics, it is necessary to recall that the stylistics analyzes the facts on the part of their functions, determining both the meaningful and expressive uniqueness of individual linguistic phenomena among others, united by common or similar main meaning. Therefore, synonymous language means constitute an essential part of the stylistic consideration" (Gvozdev, 1967). The basis of this understanding is the viewpoint of A. M. Peshkovsky when not only grammatical meanings first of all, but merely grammatical synonyms are examined and compared, which indicates the limitations of the stylistic features of morphology. However, the issue of syntactic and non-syntactic forms (forms of inflection and derivation) is specifically considered.

I.B. Golub also puts forward two approaches in the study of the parts of speech stylistics in the "Stylistics of the Russian language". The first approach offers the consideration of their use in different styles of speech and identification of the stylistic activity of certain lexico-grammatical classes and grammatical categories of different parts of speech. The second important aspect of the study is the expressive function of parts of speech and various morphological means of language (Golub, 1997).

We tend to consider the morphological features of the advertising text as part of the first approach, which reflects the two aspects of expression, namely, inflectional aspect when the unity of the advertising comes into syntactic relationship and derivational aspect when there is an expansion of the morphological paradigm. These processes may occur within the codified language according to the language norm. However, morphological processes are the most obvious and vivid within the framework of the second approach when expressivization of linguistic resources can achieve pragmatic goals and is indicative of deviation from the language norm. It is a language play in which "three phenomena are mostly made play: 1) the status of the word form as the smallest unit of the text; 2) the formal means of expression of various morphological expression units; 3) play with the semantics of morphological categories and forms"(Sannikov, 1999).

However, the researches in the field of advertising text, over time, have acquired a systemic nature, and one of these summarizing works was the publication by O.S. Issers (2009), where the author states that "the grammatical system of the language has a significant potential of speech impact, due to several intralingual factors: 1) the possibility of choosing the grammatical form from the language variants available; 2 ) the ability of using the grammatical contrast; 3 ) the possibility of forming occasional grammatical forms", thus, highlighting after E. N. Remchukova (2005) "techniques of grammar language units updating" in the advertising text.

Based on the indicated approaches to the analysis and study of the advertising text from the perspective of its morphological "appearance", we addressed the most notable works. The study of E. V. Medvedeva "Advertising Communication" (2004) in the framework of linguo-stylistic analysis provides the detailed quantitative characterization of parts of speech, and their translation peculiarities in the comparative review of English, German and Russian magazine 
advertising. This approach revealed the following patterns: the dominance of the names of objects and phenomena in all the compared languages; prevalence of usage of words indicating an attribute of an object (adjectives and participles) over the verb. This tendency is confirmed by the activation of morphological processes relating adjectives called "exaggeration". In addition, usage of predicatives in advertising, as a rule, reflects two polar trends in the use of verbal forms in imperative: from recommendatory pardonable, disguised in the form of indicative mood to aggressively imperative (Medvedeva, 2004).

The study of E. P. Dudina "Semantics and Functions of Lexico-grammatical Units in Advertising" (2006) made a strong statement about the morphological status of ad text as a stylistic unity. Only nouns, adjectives and verbs were analyzed, but the identification and justification of grammatical properties of these units allow us to make generalizations about the morphological components forming the stylistic unity of advertising.

\section{Results and Discussion}

The morphological analysis of the advertising text units primarily involves identifying their semantic features in accordance with the lexico-grammatical classes. So, the noun as a nominative unit of the text reflects the specificity of advertising communication, which demonstrates a specific combination of picture and abstract and generalized types of thinking, because there is the same representation of both abstract and concrete nouns. The study found that there are "some of the most frequent nouns in advertising language: life, peace, money, time, quality, people and price. In earlier studies, it was noted that these nouns are keywords or "semantic core advertising language" because they reflect the inherent value of modern "civilization of consumption" and form the basis of the advertising language image of the world that brings them closer to the concept (Dudina, 2006).

If we consider "the choice of the grammatical form of the available language variants" (Issers, 2009), the mentioned lexemes are characterized by a number of word forms, for example, the word "life" has more than 40 forms: Zhizn udalas! [Life is good!; Kazhdaya zhenschina dolzhna byt hot raz $v$ zhizni ryzhey! [Every woman should be red at least once in a lifetime!]; Investiruyte god zhizni v svoyo budushchee [Invest a year of life in your future]; My oformlyaem prostranstvo dlya zhizni [We make space for life]; Naslazhdaytes vkusom, naslazhdaytes zhiznyu! [Enjoy taste, enjoy life!]; My vdokhnem zhizn v vashi steny [We'll breathe life into your walls]; Izyskannoe prostranstvo dlya zhizni [Exquisite living space]; Shchemyashchie, kak vospominaniya o proshlyih zhiznyah [Pinching as the memories of past lives]; Moyo uvlechenie - zhizn! [My passion is life!]; Zhizn - horoshaya shtuka, kak ni kruti! [Life is a good thing, anyway!] The lexeme life in the advertising text, as a rule, can only have positive quality and such lexico-semantic variants as 'the way of being', 'period of existence', 'environment' carrying a positive semantics are represented.

From the perspective of grammatical forms and categories the noun is exposed to "morphological transformation or usage of the word in another, morphological category, being alien to it" (Kurganova, 2004), namely: 1) violation in the way of expressing the category of number, cf.: Germes-Finans. Vashi pribyli. (Hermes-Finance. Your profits). The word pribyli [profits] is not correlated with specific nouns and it has no singular-plural form opposition. However, copywriters, guided by communicative purposes, thus create a new emotional and meaningful effect; 2) expansion of "... the conceptual universals of quantitativeness: value, measure, degree, plurality, order and proportions", which are characterized by E. S. Kara-Murza as the activation of structures associated with the phenomenon of exaggeration: Bolshe, chem podarok [More than a gift]; Bolshe, chem prosto bank [More than just the bank]; Bolshe, chem dengi [More than money], Luchshe, chem dengi [Better than money]. Or the play with quantitativeness, i.e. measuring of principally non-measurable things: Kredit $0 \%$ [0\% Credit]; Tolko za krasivyie glaza [Only for beautiful eyes]; Eksimer - mera uspekha [Excimer is a measure of success]; Sdelay na "Tyuns» bolshe [Do it more on the Tunes]; Invite Cola. Dva litra prikola [Invite Cola. Two liters of fun]; 3) the use of a unit characteristic of advertisement belonging to another language in the inclinable form or pragmatonym in the slogan, the result is a catchy rhyme or form: Vesennyaya pora - KITEKETu ura! [It is the springtime - Hurray to KITEKAT]!; DAYSU otdaysya, drugim ne sdavaysya! [Give yourself to Dice, not to the others!] The relevance of this trend is also evident if advertising texts are semantized: "Troynaya zaschita ot L'Oreal" ["Triple protection from L'Oreal"]; "Spetsialnyiy agregat zaschity vozdukha ot Toshiba!" ["Special air protection unit from Toshiba!"], which V. A. Dolinsky in the article "The Power of Language and the Language of Power" offers to interpret as "appeals to flee from the advertised goods" (Dolinsky, 2004). This is explained by the fact that advertising texts, above all, characterized by advertising names expressed by indeclinable nouns L'Oreal, Toshiba. In these texts, according E. S. Kara-Murza, there is 'an agrammatism' - the violation of logical and grammatical connections between words within a sentence and at the junction of two independent sentences" (Kara-Murza 2003), which is expressed in "the tendency to analytism, when the grammatical meaning is no longer expressed by the word form and is conveyed by means of context", on the other hand, the analogy with 'ot kutyur' prepositional word combination which has already become a fixed collocation and 
corresponds to the French 'haute couture' denoting literally "top-level tailor" or having the second and well-known meaning of "high fashion", which generates the meaning "from the manufacturer". As a result, "Troynaya zaschita ot L'Oreal" ["Triple protection from L'Oreal"] can be interpreted in different ways: 1) similar to the meaning suggested by V. A. Dolinsky - "an appeal to flee from the advertised goods"; 2) "Triple protection (of the body with the help of a cosmetic product) from L'Oreal"; 3) "Triple protection (with the help of a cosmetic product of this cosmetic company) from L'Oreal». Thus, a violation of the semantic connection arises from the incorrectly semantized grammatical form from L'Oreal, from Toshiba.

Rigid pragmatic predetermination of advertising text demonstrates high demands on the selection of language means, including verbs. According to the well-known researcher of advertising texts A. N. Nazaykin, they "better than other parts of speech create an image, a picture in the reader's imagination. Verbs encourage and motivate well. After all, they denote the action, possess the dynamics, movement, concreteness" (Nazaykin, 2003). Addressing the problem of realization of the function of verbs in the texts of television advertising allows "defining lexico-semantic groups of verbs, the most relevant for the characteristics of the product and the recipient of television advertising, reporting a generalized image of the goods through the prism of the verbal lexicon and describing a typical conduct of the recipient of advertising modeled by the advertiser" (Korotkaya, 2007). Hence the following groups of verbs can be distinguished: 1) verbs denoting the semantic field of "attitude" that form the image of the goods which can be described as helpers, defenders, mates, donors (it is no coincidence that in the texts the advertised product is often personified), cf: "Nuts» vsegda pomozhet mozgu dobitsya zhelaemogo rezultata ["Nuts" will always help the brain to achieve the desired result], $V$ pervuyu ochered "Nuts» pomogaet mozgu [Primarily "Nuts" helps the brain], Orbit Winterfresh zashchitit zuby posle edy $i$ napolnit dykhanie prityagatelnoy svezhestyu [Orbit Winterfresh will protect your teeth after eating and fill your breathing with attractive freshness]; Novyy gel dlya dusha Johnsons s ovsyanym molochkom, medom i nezhnymi uvlazhnitelyami sohranyaet estestvennuyu myagkost kozhi [The new shower gel Johnsons with oat milk, honey and gentle moisturizers preserves the natural softness of the skin]; Kofe sdelay glotok, i novoy zhizni vitok... Tebe podarit kofe "Zhokey» [Take a sip of coffee, and coffee "Jockey" will give you a new round of life ...]; Tolko prirodnaya voda SANTA sposobna dat sily k pobede [Only natural water SANTA is able to give strength to win] (Korotkaya, 2007).

2) verbs as a means of the characteristics of the advertising communication recipient are presented by modal verbs to want, to desire, to be able, verbs denoting purchasing to buy - to have bought, to take, to get, to receive - to have received, to win; verbs of perception to watch, to hear, to feel, etc. The analysis of this group of verbs also allowed the author to conclude that "the most actual verbs in television commercials are ones relating to the subfields denoting 'the intellectual activity', 'the emotional state', 'the functional state', 'possession'. The recipient's physical actions with the goods, the recipient's movement in space and so on are irrelevant for television commercials" (Korotkaya, 2007).

The specificity of the lexico-semantic groups is accompanied by morphological phenomena. As a result of the observations the most frequent grammatical processes in verbal paradigmatics and syntagmatics characterizing the outdoor advertising are revealed:

1) "the interpretive potential of forms of mood category", noted by O. S. Issers when "with the help of the grammatical form of mood category and word order, the active and passive action can be actualized". It is expressed in the omission of the action initiator (agent and patient) and the use of indefinite-personal and impersonal constructions: "they say that (who?); It is believed that ...; It is known that ... (to whom?), etc." (Issers, 2009). For example: Tam, gde holodno i zharko, znayut, obuv - eto "Marko» [There where it is cold and hot, everyone knows: shoes mean "Marko"]; Pokupaem lom tsvetnyh metallov: Prodaem sakhar optom [We buy non-ferrous scrap: Sell sugar in bulk]; Prishel, uvidel i ...kupil! Izmenim zhizn' k luchshemu! [I came, I saw and I ...bought! Let us change life for the better!]; Vremya menyat' obuv' [It is time to change shoes]; Aktual'. Aktual'no byt' molodym! [Actual. It is actually to be young!]; Sok "Chempion». Stoit tol'ko zahotet'! [Juice "Champion". One has only to want!] The absence of an initiator of action, suggests that a well-known fact is reported in the advertising text.

2) expansion of forms of the imperative mood paradigm and the dynamics of their use in advertising also attracts attention. The use of predicatives in advertising, as a rule, reflected the two polar positions in verb forms of the imperative mood: from recommendatory pardonable veiled in the forms of indicative mood, which occurs less and less, to the imperative one, cf.: Nas rekomenduyut druzyam [We are recommended to friends]; Dumaem global'no, deystvuem moral'no [We think globally, act morally]; Napolnim skidkami bokal! [Let us fill the glass with discounts!]; Bolshie skidki dlya bolshih lyudey [Big discounts for big people]; Esli vy znaete kak, my znaem gde...[If you know how, we know where ...]; Italyanskie kolgotki...ikh nado nosit [Italian tights ... they must be worn], which was replaced by a more declarative form: try, make, call, come, hurry ... etc. It is worth to note that the imperative mood in modern texts has become increasingly used in singular form, which gives the 
slogan the conversational character and at the same time specifies the recipient. For example: REFORMA mebel' peremen [REFORMA is furniture of changes]; Prosto sravnite tseny [Simply compare prices]; Prosto dobav' vody! [Just add some water!]; or more categorical: Ne prospi pervyiy zvonok! [Not to oversleep the first bell!]; Zharko - pey HOOP! [It is hot - drink HOOP!]; Sdelay pauzu, skushay Twix! [Make a pause to eat Twix!]; Nadoel obman - prikhodi k nam [Tired of hype - come to us].

However, the potential possibilities of the language in the selection of some grammatical forms cause explicit rejection. In the article "The Power of Language and the Language of Power" V. A. Dolinsky writes: "Advertising texts became the field of battle with the language. "Naslazhdaytes konditsionerami ot torgovoy gruppy 'Belaya gvardiya!!" ("Enjoy the air conditioning of the trade group 'The White Guard'!"). "Morshchiny? Zabudte ob etom!" ("Wrinkles? Forget about this!") "Vyiigray million!" ("Win a million!") Forget, win, enjoy - in Russian imperative mood of such verbs is unthinkable (Dolinsky, 2004). Noting the violation of logicalsemantic relationships in these verbs (zabudte, vyiigrayte, naslazhdaytes [forgetr, win, enjoy]), we can easily continue a number of similar verbal forms in texts like: Prihodi. Prazdnuy. I POBEZHDAY! [Come. Celebrate. And WIN!]; Ustremi vzor v novyiy televizor [Fix yours eyes on a new TV], which indicates the activation of the imperative form of the singular as potential members of a verbal paradigm, although rarely used in the speech.

3) substantiation of the target audience, namely the youth one, explains the activation not only of the imperative mood in the singular form, but also the use of slang expressions, which are the result of one of the most productive ways of aspect formation: Zasvetis' na red.mts.ru i poluchi IPhone [Be spotted at red.mts.ru and get IPhone]; Zatsepi komandu AXE - Zatseni krutoy relAKS! [Hook the team AXE - Cast a spell of cool relax!]; Zazhigay po polnoy! [Bring it on in spades!]; and also the formation of occasional grammatical forms; Zaryadis' - Osvezhis' - Zaklubis'! [Charge yourself - freshen yourself - get swirled!]; Zazvoni ikh vsekh! [Ring them all!]; Maksimiziruysya! [Maximize yourself!]

An important role in the formation of figurative-expressive structure of a slogan is played by adjectives. Obviously, the ad text is more often represented by a nominal type of speech, which explains the highly frequent occurrence of adjectives in advertising. The studies have shown that the most frequent adjective new relates to "the basic meanings 'change', 'improvement', which are represented by nouns of high frequency" (Dudina, 2006).

The general trend to the intensification of a feature is explained by activation of morphological processes in the field of adjectives called 'exaggeration". As a result, in the field of adjectives we observe: 1) the transition of relative adjectives into qualitative ones, and this process is accompanied by the acquisition of grammatical categories of qualitativeness by relative adjectives, they are the degrees of comparison, the superlative form. On the other hand, there is the increase of lexical compatibility, which is obvious because the grammatical processes are affected.

Explaining and detailing these phenomena, we must add that the connotative structure of the slogan explains the predominance of qualitative adjectives in advertising, which in turn gives rise to "the increase of qualitativeness" in relative adjectives. O.S. Issers calls this process "one of the common ways to overcome the "failure" (i.e. lexical and grammatical resources of literary language), which is the use of relative adjectives in the meaning of qualitative ones" (ibid, 2009). The manifestation of opportunities of the formation of occasional grammatical forms is observed when creating degrees of comparison of adjectives, which are widely used in the language of modern advertising, for example: the comparative degree forms: Kirpichnee kirpicha ne byivaet [There is no bricker brick!]; Limonnee limonov [More lemon than lemons]; Yagodnee yagod [Berrier than berries]; superlatives: Samyiy frantsuzskiy potseluy [The most French kiss]; Samyiy igrushechnyiy magazine [The toyest toy shop]; Samyiy mayoneznyiy mayonez [The mayonnaisest mayonnaise]; Samaya vishnevaya zaschita ot kariesa[The cherriest protection against tooth decay]. There is quite a noticeable trend in the expansion of the paradigm of relative adjectives through the degree of comparison formation. The occasionality is created due to formally unconditioned meaning of the qualitativeness in the generated forms, but the grammatical meaning in spite of everything enriches and extends the semantics of the adjective. Another trend relating to adjectives is found: the violation (or extension?) of the lexical combinability in the word combination due to the personification, cf.: Umnyie igrushki [Smart toys]; Umnyy telefon [Smart phone]; Intellektualnyy telefon [Smart phone]; Umnyie divany [Smart sofas]; Umnaya krasota. ROWENTA [Smart beauty. ROWENTA]; Apigurt. Veselaya vkusnyatina [Apigurt. Funny yummy]; Vesyolaya po vkusu, chistaya po prirode. Voda Senezhskaya [Merry in taste, clean in nature. Senezhskaya water]; Zhivoe morozhenoe iz zhivogo moloka [Live ice cream from the live milk]; Bestseremonnyy viski po chestnoy tsene [Unceremonious whiskey at a fair price]. Especially frequent are characteristics of beer: pravilnoe pivo [proper beer], prodvinutoe pivo [advanced beer], dushevnoe pivo [sincere beer]. The popularity and effectiveness of this technique as another indicator of personification explains the thesis put forward by E. N. Zaretskaya: "If the properties and typical human behavior are transferred to inanimate objects, the importance of the latter is extremely increased. This is the maximum expression of the transfer of meaning" (Zaretskaya, 1998). Thus, the personification means the increasing 
value of the goods for many advertisers.

Attention is drawn to the following combinations: Tvoy sochnyiy stil; President - takoy syrnyy syr! [Your juicy style; President is a cheesy cheese!]; Chupa-Chups. Kruglaya radost' [Chupa Chups. Round joy]; Rusagro. Fruktovyy den kalendarya [Rusagro. Fruit calendar day]; Frustail. Naturalnoe udalenie zhazhdyi. Legkovaya zhizn [Frustyle. Natural removal of thirst. Sedan life]; Shokoladnyie otnosheniya sozdayutsya shokoladnymi podarkami. Konfael [Chocolate relationships are created by chocolate presents. Confael]. From a grammatical point of view, there is the actualization of such features, in which the relative adjectives have the properties of qualitative ones, preserving their relative meaning which allows endowing objects with unusual, but impressive and memorable qualities. This process of expansion of the lexico-grammatical features of word forms is the most significant in slogans, where "the qualitativisation" of relative adjectives is confirmed by the analytical form of superlatives: Samye pelmenistyie pelmeni v mire! [The most dumpling dumplings in the world!]; Samaya telefonistaya model [The most telephonist telephone model]; "Baltimor" - samyy provansalnyy provansal ["Baltimore" is the provensaliest provensal].

\section{Summary}

"Advertising" language is the result of the work of specialists of many branches of knowledge, starting from philologists and linguists and ending with copywriters and psychologists. The language in the advertisement must meet the following criteria: a minimal amount of text should have the maximum number of memorable and convincing information, at the same time, of course, we cannot forget about the ethical, grammatical and other rules and regulations. Linguo-pragmatic approach in the study of the advertising text consistently demonstrates two mutually conditioned processes, which are contrastive: on the one hand, a reflection of active processes occurring in the Russian language in everyday speech. On the other hand, the emergence and functioning of these forms, which show a deliberate use of non-regulatory, noncodified grammatical forms having rather the equivoque character than the wrong one in most cases. Obviously, this fact once again brings us back to understanding of the advertising text as a complex multi-aspect unit possessing a pragmatic dominant.

\section{Conclusion}

Separate lexemes are functionally conditioned by the representation of some of the most striking trends in the grammatical language of advertising text:

1. The expansion of the lexical and grammatical word forms characteristic of realization of nominal parts of speech. There are two ways concerning noun: changing the logical and semantic concepts related to the quantitativeness, the use in correlative forms of singular and plural of abstract nouns, not having earlier the form of the plural; the adaptation of proper names of foreign origin as the declinable units. As for the adjective we can observe the intensification of "the qualitativeness" process in relative adjectives, which is expressed in the formation of comparative and superlative degrees.

2. Despite the fact that the verbal lexeme is considered to be less active than adjectives in some studies, the stability and frequency of some of the processes that are inherent in advertising communication should be noted: 1) the use of the imperative form of the verb, both of existing and potential or occasional; 2) the formation of the image of the goods as helpers through verbal lexeme or the personification of goods through actions that are typical of man.

3. Observation, and then an analysis of linguistic material suggest that the ad text as a vivid stylistic phenomenon often reflects active processes specific to the language and media text in particular. But the manifestation and activation of grammatical processes in the advertising text testifies not only to expansion of the arsenal of means of expression, but also the intensive grammatical shifts caused by both internal linguistic and external factors.

\section{References}

Bally Ch. (2001). Frantsuzskaya stilistika [French Stylistics]. - Moscow. (P. 272). [in Russian].

Bazhenova, E. A., \& Protopopova, O. V. (2003). Yazyik i stil reklamyi [The language and Style of Advertising] Stilisticheskiy entsiklopedicheskiy slovar. - Moscow. (pp.635-642). [in Russian]. .

Bedanokova, Z. K., Bedanokova, S. K. (2010). Grammaticheskie protsessy v reklamnom tekste kak stileobrazuyuschee sredstvo [Grammatical Processes in Advertising Text as a Style Forming Means]. Russkyy yazyik: istoricheskie sudby i sovremennost: 4 
Mezhdunarodnyy kongress issledovateley russkogo yazyika. - Moscow. (P. 162) [in Russian].

Bedanokova, Z. K. (2010). Grammaticheskiy komponent v stilistike reklamnogo teksta [The Grammatical Component in the Style of the Advertising Text]. Izvestiya Yuzhnogo Federalnogo universiteta. Filologicheskie nauki. - Rostov-on-Don. No.3. (pp.76-83) [in Russian].

Benveniste, E. (1966). Urovni lingvisticheskogo analiza [Levels of Linguistic Analysis]. Dokladyi 1H Mezhdunarodnogo kongressa lingvistov. Retrieved from: http://www.classes.ru/grammar/151.new-in-linguistics-4/source/worddocuments/_15.htm [in Russian].

Benveniste, E. (1974). Obschaya lingvistika [General Linguistics]. - Moscow. (P.275). [in Russian].

Dolescha, U. (2001). Das Phanomen der Unflektierbarkeit in den siawischen Sprachen, Habilitationsschrift. Wien, (S.260).

Dolinskyy, V. A. (2004). Vlast yazyika i yazyik vlasti [The power of Language and the Language of Power]. Materialy 2 Mezhdunarodnogo kongressa issledovateley russkogo yazyika. - Moscow. (pp. 357-358). [in Russian].

Dudina, E. B. (2006). Semantika i funktsii leksiko-grammaticheskih edinits v reklame [Semantics and Functions of the Lexicogrammatical Units in Advertising]. Diss. ... kand. filol. nauk. - Severodvinsk (P.275). [in Russian].

Glovinskaya, M. Ya. (1996). Aktivnyie protsessy v grammatike (na materiale innovatsiy i massovyh yazyikovyi oshibok) [Active Processes in the Grammar (Based on Innovation Material and the Mass of Linguistic Errors)]. Russkiy yazyik kontsa XX stoletiya (1985-1995). - Moscow. (pp.237-304). [in Russian].

Glovinskaya, M. Ya. (2008). Aktivnyie protsessyi v grammatike [Active Processes in the Grammar]. Sovremennyiy russkiy yazyik. Aktivnyie protsessyi na rubezhe XX-XXI vekov. - Moscow. (pp.187-270) [in Russian].

Golub, I. B. (1997). Stilistika russkogo yazyika [Stylistics of the Russian Language]. - Moscow. (P. 448). [in Russian].

Gvozdev, A. N. (1967). Stilistika sovremennogo russkogo yazyika [The Stylistics of the Modern Russian Language]. - Moscow. (P. 448). [in Russian].

Issers O. S. (2009). Rechevoe vozdeystvie [Speech Influence]. - Moscow. (P. 68) [in Russian].

Kara-Murza, E. S. (2003). Divnyiy mir rossiyskoy reklamyi [Wonderful World of Russian Advertising]. Retrieved from: http://www. gramota.ru [in Russian].

Kokhtev, N.N. (1997). Reklama: iskusstvo slova [Advertising: The Art of the Word]. Rekomendatsii dlya sostaviteley reklamnykh tekstov. - Moscow. (P.96). [in Russian].

Korotkaya S. N. (2007). Glagolnyie leksemy kak sredstvo harakteristiki tovara i adresata v tekste telereklamy [Verb Lexemes as a Means of Product and the Recipient Characteristics in the Text of TV Commercials]. Russkaya slovesnost v kontekste mirovoy kulturyi. Nizhniy Novgorod. (pp. 220-223) [in Russian].

Kozhina, M. N. (2008). Stilistika russkogo yazyika: uchebnik [Stylistics of the Russian Language]. - Moscow. (P. 464). [in Russian].

Kurganova, E. B. (2004). Igrovoy aspekt v reklame [The Playing Aspect of Advertising]. - Voronezh. (P. 260). [in Russian].

Medvedeva, E. V. (2004). Reklamnaya kommunikatsiya [Advertising Communication]. - Moscow. (P. 278). [in Russian].

Nazaykin, A. N. (2003). Praktika reklamnogo teksta [The Practice of Advertising Text]. - Moscow. (P. 320). [in Russian].

Remchukova, E. N. (2010). Kreativnyy potentsial russkoy grammatiki [The Creative Potential of the Russian Grammar]. - Moscow. (P. 224). [in Russian].

Römer, R. (1980). Die sprache der Anzeigenwerbung. - Dusseldorf: Schwann.

Sannikov, V. Z. (1999). Russkiy yazyik v zerkale yazyikovoy igry [Russian Language in the Mirror of Language Play]. - Moscow. (P. 552). [in Russian].

Sirotinina, O. B. (2003). Horoshaya rech, sdvigi v predstavlenii ob ee etalone [Good Speech, Changes in the Idea of its Standard]. Russkiy yazyik segodnya 2. Aktivnyie yazyikovyie protsessyi kontsa XX veka. - Moscow. (pp.548-555). [in Russian].

Valgina, N. S. (2003). Aktivnyie protsessyi v sovremennom russkom yazyike [Active Processes in the Modern Russian Language]. Moscow. (P. 303). [in Russian].

Valladares, J. (2005). Remeslo kopiraytinga [Copywriting Craft]. - St-Petersburg. (P. 272). [in Russian].

Vinogradov, V. V. (1950). Stilistika sovremennogo russkogo yazyika [The Stylistics of the Modern Russian Language]. - Moscow. (P. 412). [in Russian].

Wells W. D., Burnett J., Moriarty S. (2000). Reklama: printsipyi i praktika [Advertising: Principles and Practice ]. - Moscow. (P. 797). [in Russian].

Zaretskaya, E. N. (1998). Ritorika: Teoriya i praktika rechevoy kommunikatsii [Rhetoric: the Theory and Practice of Speech Communication]. - Moscow. (P. 480). [in Russian]. 